\title{
Formation and significance of transparent exopolymeric particles in the northern Adriatic Sea
}

\author{
Stefan Schuster, Gerhard J. Herndl * \\ Institute of Zoology, University of Vienna, Althanstr. 14, A-1090 Vienna, Austria
}

\begin{abstract}
We examined the abundance and bacterial colonization pattern of transparent exopolymeric particles (TEP) during 2 different ecological conditions along a trophic gradient in the northern Adriatic Sea. Generally, neither TEP density (ranging from 0 to $600 \mathrm{TEP}^{-1} \mathrm{l}^{-1}$ ) nor mean TEP area were found to be correlated with chlorophyll a concentrations, although a tendency was discernible of increasing TEP density and area towards more eutrophic conditions. TEP area ranged from 12 to $7500 \mu^{2}$ with TEP-attached bacteria inversely correlated with TEP aera. In laboratory experiments using water amended with dissolved organic matter released by a Chaetoceros sp. batch culture, we examined the influence of bacteria and turbulence on the formation of TEP. In both biotic and abiotic treatments subjected to turbulence. TEP density and area reached maximum levels within $24 \mathrm{~h}$ and retained this level over a period of $\sim 40 \mathrm{~h}$. In the stagnant treatment, however, TEP area declined rapidly after reaching a peak $\sim 24 \mathrm{~h}$ after starting the experiment. Based on our experments, we conclude that turbulence of the water column is more important than bacteria in the formation of TEP. In situ fluctuations in TEP abundance might reflect not only differences in phytoplankton growth stage but also different turbulent regimes.
\end{abstract}

KEY WORDS: Exopolymers · Colloidal matter - Bacteria - Phytoplankton - Northern Adriatic Sea

\section{INTRODUCTION}

Photosynthetic extracellular release (PER) of phytoplankton represents a significant loss of photosynthetically fixed carbon to the surrounding water (Myklestad \& Haug 1972, Fogg 1977). Studies have shown that between 1 and $-80 \%$ of the photosynthetically fixed carbon is released into the ambient water (Chrost \& Faust 1983, Myklestad et al. 1989, Kaltenböck \& Herndl 1992). It has also been demonstrated that both the percentage and the molecular weight distribution of this PER increase from juvenile to senescent stages of phytoplankton (Chrost \& Faust 1983, Obernosterer \& Herndl 1995). The percentage of PER is low in juvenile phytoplankton but the absolute amount in terms of carbon released is higher than in senescent stages (Lancelot 1983, Obernosterer \& Herndl 1995). The percentage as well as the molecular weight distribution of the PER is also significantly influenced by the nutrient

\footnotetext{
-Addressee for correspondence;

E-mail: gerhard.herndl@univie.ac.at
}

availability. Nutrient depletion, like every other stress, results in elevated PER rates (Obernosterer \& Herndl 1995). Especially phosphorus limitation has been frequently suggested to be responsible for excessive formation of mucilage (Myklestad \& Haug 1972, Fogg 1990). In the northern Adriatic Sea, for example, Kaltenböck \& Herndl (1992) found PER rates of up to $80 \%$ under severe $\mathrm{P}$ limitation. It has been speculated that excessive mucilage production may be responsible for the occurrence of massive marine snow occasionally detectable in the northern Adriatic (Herndl 1992). Recently, Obernosterer \& Herndl (1995) showed that PER derived from P-depleted phytoplankton cultures is more resistant to bacterial degradation than nutrientrepleted cultures, further supporting the hypothesis that P-limited phytoplankton release copious amounts of more refractory, high molecular weight PER.

This high molecular weight PER consists of polymeric fibrils (Decho 1990), frequently termed extracellular polymeric substances' (EPS). Almost all aquatic organisms produce EPS including prokaryotes and microand macroalgae (Aaronson 1971, Painter 1983, Hoag- 
land et al. 1993). These EPS consist of polysaccharides with a wide variety of simple sugars (Lewin 1956, Hoagland et al. 1993); the quantity as well as the quality of EPS produced might vary according to the organisms releasing them. EPS can either occur as tight capsules surrounding microbial cells or as dispersed slime in no apparent association with cells (Decho 1990). Thus, EPS may occur in both colloidal and particulate form; therefore, colloidal EPS are operationally classified as part of the 'dissolved organic matter' (DOM) pool because they pass, at least partly, through $0.45 \mu \mathrm{m}$ filters (Burney 1986). Recent studies show that small colloids ( 5 to $200 \mathrm{~nm}$ ) are the most abundant particles in seawater, reaching concentrations of $10^{9}$ particles $\mathrm{ml}^{-1}$ (Koike et al. 1990, Wells \& Goldberg 1991. 1992, 1993). This high density and the size distribution of sub-micrometer particles led to the conclusion that a significant portion (at least $10 \%$ ) of the DOM pool may in fact be in the form of these particles (Koike et al. 1990, Kepkay et al. 1993, Kepkay 1994).

The process by which excreted exopolymers form colloids has been documented in freshwater using TEM techniques (Leppard et al. 1977, Strycek et al. 1992) and more recently in marine waters (G. G. Leppard unpubl.). Benner et al. (1992) found that in surface waters more than $30 \%$ of the DOM is colloidal and comprises up to $\sim 50 \%$ of the 'reactive' polysaccharides. Following a phytoplankton bloom, Kepkay et al. (1993) detected a shift from low molecular weight DOM to colloidal matter during the transition from a juvenile to a senescent stage of a bloom. This colloidal matter may serve as nuclei for aggregation to larger particles and thereby effects significantly sedimentation processes of organic matter (McCave 1984, Kepkay 1994). Although this coagulation of originally dispersed colloidal matter might eventually also lead to the formation of mucus sheets onto which living and dead particles become attached, known as marine snow', the flocculation of phytoplankton to form large aggregates leads more directly to marine snow (Herndl in press). Kiørboe et al. (1990) showed that one key factor determining the potential in aggregate formation is phytoplankton stickiness described as the probability of adhesion upon collision. In some diatom species, the cells themselves are sticky and coagulate without any mucus, while other diatoms extrude EPS and thereby increase cell stickiness. Aggregates of these diatoms consist of a mixture of mucus and cells.

Recently, Alldredge et al. (1993) described a new class of particles: transparent organic particles, formed from polysaccharides excreted presumably by phytoplankton and/or bacteria. These transparent exopolymeric particles (TEP) range from 28 to 5000 particles $\mathrm{ml}^{-1}$ (Alldredge et al. 1993). Passow et al. (1994) found that TEP of diatom origin cause aggregation of the diatom Chaetoceros gracilis. TEP are composed of colloidal fibrils, rich in acidic mucopolysaccharides (Decho 1990). The high amount of cations $\left(\mathrm{Ca}^{++}\right.$and $\mathrm{Mg}^{++}$) as well as the disaggregation of TEP after addition of EDTA indicates that these fibrils are aggregated primarily via cationic bridging (Alldredge et al. 1993). It has been suggested that the formation of TEP from polysaccharide fibrils ( 3 to $10 \mathrm{~nm}$ in diameter) is similar to that described for freshwater systems (Burnison \& Leppard 1983, Leppard 1986, Leppard \& Burnison 1990). Alldredge et al. (1993) found 28 to $68 \%$ of the total bacterial community attached to these TEP suggesting that they may have a significant impact on the distribution of marine microbes by creating a specific microenvironment.

The purpose of the present study was to follow the density of TEP along a trophic gradient in the northern Adriatic Sea under different ecological conditions and to determine the origin and fate of these TEP. Experiments were conducted to test the relative importance of phytoplankton as compared to bacteria in the formation of TEP. Another objective of this study was to decipher the role of turbulence in TEP formation and decay.

\section{MATERIAL AND METHODS}

Study area and sampling procedure in the field. Water samples were taken along a trophic gradient in the northern Adriatic Sea from the oligotrophic eastern part to the eutrophic western part ffrom $45^{\circ} 4.8^{\prime} \mathrm{N}, 13^{\circ} 36.6^{\prime} \mathrm{E}$ to $44^{\circ} 59.9^{\prime} \mathrm{N}, 12^{\circ} 49.8^{\prime} \mathrm{E}$ ) on board the RV 'Vila Velebita' during 2 cruises (17 August and 18 October 1993; Fig. 1). This part of the

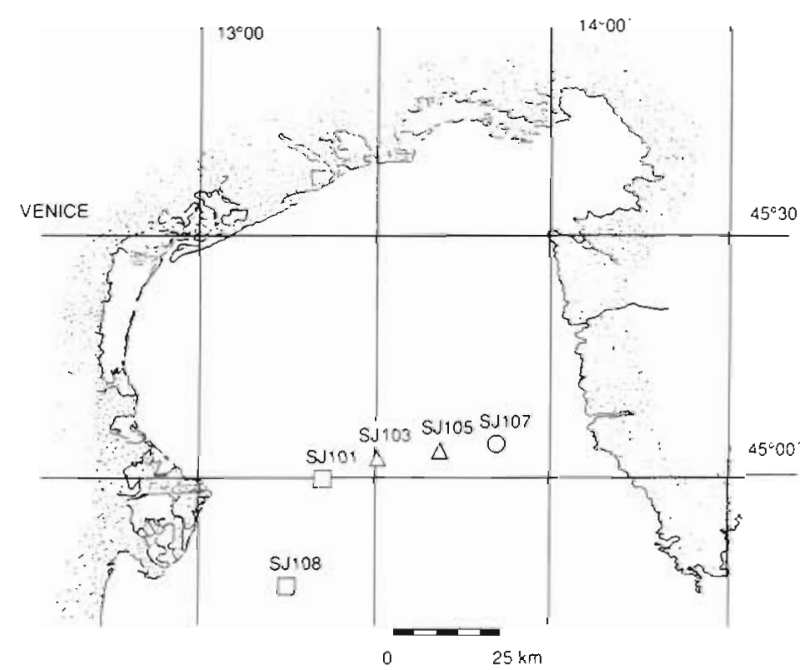

Fig. 1. Sampling stations in the northern Adriatic Sea. Samples were taken following a trophic gradient from oligotrophic (SJ107) towards eutrophic (SJ101, SJ108) regions; sampling was performed within $1 \mathrm{~d}$ 
northern Adriatic Sea is characterized by a counterclockwise current system which transports oligotrophic waters along the eastern (Croatian) coast to the north. The western part of the northern Adriatic Sea is influenced by large river systems like Po and Isonzo, which significantly contribute to the nutrient load of the northern Adriatic Sea (Degobbis et al. 1979, Smodlaka \& Revelante 1984). Water samples were taken with pre-rinsed $(0.1 \mathrm{~N} \mathrm{HCl})$ Niskin bottles close the surface $(0.5 \mathrm{~m})$ and at 5,10 and $20 \mathrm{~m}$ depth. An additional sample was taken $3 \mathrm{~m}$ above the bottom. From each Niskin bottle, subsamples were taken to determine the abundance of TEP and bacteria; subsamples were also taken for chlorophyll $a$ (chl a) and dissolved organic nutrients as described below.

Concurrently with the sampling of water, CTD hydrocasts were perfomed using a SeaBird multiprobe equipped with a fluorometer calibrated with a standard solution of chl $a$.

Laboratory experiments. Phytoplankton cultures: The development of TEP was followed in phytoplankton batch cultures using Chaetoceros sp. and a mixed natural phytoplankton community from the northern Adriatic Sea, respectively. Chaetoceros sp. as well as the mixed phytoplankton culture $(4.5 \mathrm{l})$ were grown in $0.2 \mu \mathrm{m}$ double-filtered (Millipore, polycarbonate), autoclaved and slightly modified $\mathrm{f} / 2$ medium (Parsons et al. 1984). All cultures were grown at $18^{\circ} \mathrm{C}$ at an irradiation of $\sim 100 \mu \mathrm{E} \mathrm{m}^{-2} \mathrm{~s}^{-1}(12 \mathrm{~h}$ light: $12 \mathrm{~h}$ dark cycle, white cool lamps). Turbulence was generated by placing the culture flasks on a rolling table at 0.5 rpm (Shanks \& Edmondson 1989). Subsamples of $5 \mathrm{ml}$ were taken from duplicate flasks once a day and the abundance of TEP, percentage of TEP-attached bacteria and the number of free-living bacteria determined as described below. The growth phase of the phytoplankton cultures was monitored by measuring the optical density (OD) of the culture at $550 \mathrm{~nm}$ wavelength using a spectrophotometer (Hitachi U2000).
Role of turbulence and bacterial activity on the formation of TEP derived from photosynthetic extracellular release. Four flasks were filled with previously filtered seawater $(250 \mathrm{ml}$, Whatman GF/F) derived from a senescent culture of Chaetoceros sp. Two of the flasks were agitated on a rolling table $(3 \mathrm{rpm}$, estimated energy dissipation rate $-0.06 \mathrm{~cm}^{2} \mathrm{~s}^{-3}$; Moeseneder pers. comm.) while the remaining 2 were left undisturbed. One flask of each treatment was fixed with formalin ( $2 \%$ final conc.) in order to prevent microbial activity. All flasks were incubated in the dark at $18^{\circ} \mathrm{C}$ and sampled at irregular intervals for bacterial density and TEP abundance.

Enumeration of TEP and bacterial abundance. Prior to rountinely enumerating TEP, the efficiency of various pore sizes in retaining the stained TEP was tested (Table 1). Raw seawater was collected in the northern Adriatic Sea about $1 \mathrm{~km}$ off the Center for Marine Research, Ruder Boskovic Institute at Rovinj (Croatia). It was then brought to the laboratory, stained with Alcian Blue and subsequently with DAPI (as described in detail below), and filtered sequentially onto polycarbonate filters of various pore sizes $(0.6 \mu \mathrm{m}, 0.45 \mu \mathrm{m}$ and twice through $0.2 \mu \mathrm{m}$; all filters Millipore polycarbonate). As shown in Table 1, $0.45 \mu \mathrm{m}$ filtration retained about $73 \%$ of the bacterial community and a single $0.2 \mu \mathrm{m}$ filtration retained $99.7 \%$ of the bacterial community and $77 \%$ of the TEP were retained by a single $0.2 \mu \mathrm{m}$ filtration. The TEP which passed through the initial $0.2 \mu \mathrm{m}$ filter were subsequently collected by the second filtration and were, in terms of area, about 1 order of magnitude smaller than those collected in the first filtration step. This indicates that small TEP either passed through $0.2 \mu \mathrm{m}$ filtration or that small TEP were formed during the filtration step. We also compared the influence of formalin on TEP by comparing TEP previously fixed with formalin ( $2 \%$ final conc.) with untreated TEP; no significant differences were found neither in density nor in size.

For enumeration of TEP and bacteria, $5 \mathrm{ml}$ samples were double-stained first with Acridine Orange (for

Table 1. Retention efficiency of bacteria, flagellates and transparent polymeric particles (TEP) on polycarbonate filters of different pore sizes $(0.6,0.4$, and $0.2 \mu \mathrm{m}$ Millipore filters). Double filtration through $0.2 \mu \mathrm{m}$ filters was used as reference (100\%); 3 replicate experiments were performed; mean TEP area was calculated from 20 TEP sized per filtration. Range is given in parentheses

\begin{tabular}{|cccccc|}
\hline Treatment & Bacterial density (\%) & Flagellate density (\%) & TEP density (\%) & Total TEP area (\%) & Mean TEP area $\left(\mu \mathrm{m}^{2}\right)$ \\
\hline $0.2 \mu \mathrm{m}$ & 99.74 & 100.00 & 76.92 & 94.56 & 158.21 \\
& $(80.74-117.89)$ & $(56.40-160.14)$ & $(69.45-92.60)$ & $(65.73-119.34)$ & $(87.55-211.93)$ \\
$0.4 \mu \mathrm{m}$ & 73.39 & 28.09 & 0 & 0 & 0 \\
$0.6 \mu \mathrm{m}$ & $(67.55-80.81)$ & $(18.80-37.60)$ & & 0 & 0 \\
& $(45.45-69.35)$ & $(18.79-18.80)$ & & & 0 \\
\hline
\end{tabular}


1 min; Hobbie et al. 1977) or DAPI (for 10 min; Porter \& Feig 1980), respectively. Subsequently, the stained sample was filtered onto a black polycarbonate filter (Millipore, pore size $0.2 \mu \mathrm{m}$ ) with a suction pressure of $<200$ mbar. Immediately thereafter, while still under suction pressure, $300 \mu \mathrm{l}$ of an aqueous solution of Alcian Blue $(0.2 \%$ in $0.6 \%$ acetic acid, $\mathrm{pH} 2.5 ; 0.2 \mu \mathrm{m}$ filtered) was placed onto the wet filter and allowed to stain for $<5 \mathrm{~s}$. Thereafter, the filter was embedded in paraffin oil and the abundance of TEP and the percentage of bacteria attached to TEP determined. TEP were enumerated either under a transmission microscope or under epifluorescence microscope ( $\times 1250$ magnification for both). Both techniques yielded TEP abundance and areal estimates not significantly different from each other (data not shown). Bacterial abundance attached to TEP as well as free-living bacteria were enumerated under the epifluorescence microscope (Leitz Laborlux S equipped with a Ploemopak epiffurescence unit). The size of TEP was determined directly using an ocular micrometer. The area of a TEP was calculated from its longest dimension multiplied by the width of the TEP. The areas of at least 10 TEP were calculated per sample and the calculated mean area per particle was then multiplied with the mean number of TEP $\mathrm{ml}^{-1}$ to obtain the mean area of TEP $\mathrm{ml}^{-1}$. The standard deviation was always $<50 \%$ of the mean area of TEP per samples. For enumeration of free bacteria at least 300 bacteria per sample were counted.

Chlorophyll a content. To estimate phytoplankton biomass along the trophic gradient in the northern Adriatic Sea, 11 of water was filtered onto a glass fiber filter (Wathman GF/F, $47 \mathrm{~mm}$ diameter) and kept frozen $\left(-20^{\circ} \mathrm{C}\right)$ until analysis. For chl a determination, filters were extracted in $10 \mathrm{ml}$ of $90 \%(\mathrm{v} / \mathrm{v})$ acetone and stored refrigerated overnight. Before measuring. the extraction was filtered again through a GF/F filter to remove particles. The formula given in Parsons et al. (1984) was used to calculate chl a concentrations.

Dissolved free (DFAA) and dissolved combined amino acids (DCAA). Subsamples for DFAA and DCAA were filtered through precombusted glass fiber filters $\left(480^{\circ} \mathrm{C}\right.$ for $4 \mathrm{~h}$, Whatman $\mathrm{GF} / \mathrm{F}, 25 \mathrm{~mm}$ diameter) and kept frozen $\left(-20^{\circ} \mathrm{C}\right)$ in precombusted ampoules until analysis. Dissolved amino acids were measured by high-performance liquid chromatography (HPLC) (Merck-Hitachi) using the OPA-reversed phase chromatography method (Mopper \& Lindroth 1982). For DCAA analysis, the samples were hydrolyzed under nitrogen with $6 \mathrm{~N} \mathrm{HCl}$ (final conc.) at $110^{\circ} \mathrm{C}$ for $22 \mathrm{~h}$. After hydrolysis, the $\mathrm{HCl}$ was removed by evaporating the liquid under vacuum (200 mtorr) at $5^{\circ} \mathrm{C}$. The remaining precipitate was brought up to the original sample volume with HPLC-grade distilled water (Merck). Complete dissolution was achieved using an ultrasonicator, Of this solution, $30 \mathrm{ml}$ was directly injected into the HPLC. All amino acid determinations were performed in duplicates.

Dissolved monomeric (DMCHO) and total carbohydrates (DTCHO). Dissolved carbohydrates were determined using the MBTH-method (Johnson \& Sieburth 1977) as described in Parsons et al. (1984). Subsamples for DMCHO and DTCHO analysis were filtered through precombusted glass fiber filters (Whatman GF/F, $25 \mathrm{~mm}$ diameter) and kept frozen $\left(-20^{\circ} \mathrm{C}\right)$ in precombusted ampoules until analysis. Samples for DTCHO were hydrolyzed as described above. The remaining powder was dissolved in $5 \mu \mathrm{l}$ of Milli-Q-water Samples were neutralized with $0.05 \mathrm{~N}$ $\mathrm{NaOH}$ until a whitish precipitate appeared; measurements were performed in triplicates with 2 blanks using glucose as standard.

\section{RESULTS}

\section{Field sampling}

Data from various sampling stations along the trophic gradient are compiled for sake of clarity. During the cruise on 17 August 1993 no strong pycnocline was developed (Fig. 2). At all sampling stations, chl a concentrations increased from the surface waters to -25 $\mathrm{m}$ depth and declined thereafter again; at the oligotrophic station the peak in chl a just above the weakly developed pycnocline was most pronounced (Fig. 2), Generally, neither TEP abundance nor mean TEP area were found to be correlated with chl a concentrations or depth. At the oligotrophic station, TEP were absent at $5 \mathrm{~m}$ depth and highest at $20 \mathrm{~m}(600$ $\mathrm{ml}^{-1}$; Fig. 2). At the mesotrophic stations TEP abundance increased from the surface layer down to $20 \mathrm{~m}$ depth, while at the eutrophic stations TEP concentrations ranged from $0.6 \times 10^{3} \mathrm{ml}^{-1}$ to $2.43 \times 10^{3} \mathrm{ml}^{-1}$ (Fig. 2). The mean TEP area per particle was $461.6 \mu \mathrm{m}^{2}$ $(\mathrm{SD}=180.8, \mathrm{n}=6)$ at the oligotrophic station, $454.3 \mu \mathrm{m}^{2}$ $(\mathrm{SD}=56.2, \mathrm{n}=11)$ at the mesotrophic, and $720.2 \mu \mathrm{m}^{2}$ $(\mathrm{SD}=858.8, \mathrm{n}=10)$ at the eutrophic stations. Total bacterial abundance was higher in the surface layer than in the layer between 10 and $20 \mathrm{~m}$ depth and increased again towards the bottom (Fig. 3). The percentage of TEP-attached bacteria was, on average, $0.57 \%(\mathrm{SD}=0.32, \mathrm{n}=6)$ at the oligotrophic station, $1.87 \%(\mathrm{SD}=1.60, \mathrm{n}=11)$ at the mesotrophic stations, and $4.92 \%(\mathrm{SD}=8.92, \mathrm{n}=10)$ at the eutrophic stations. While the percentage of TEP-attached bacteria averaged over the water column was generally $<5 \%$, the highest proportion of TEP-attached bacteria was $26.3 \%$ at the $5 \mathrm{~m}$ depth layer of the most eutrophic station (SJ108). Total DCAA and DFAA ranged fram 381.8 


\section{oligotrophic}

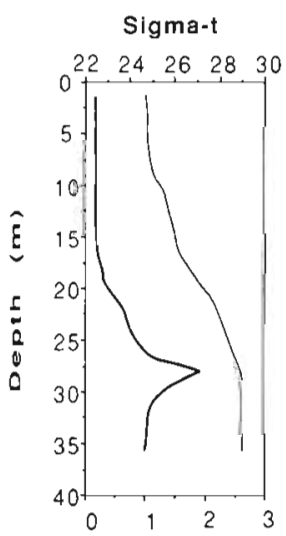

Chlorophyll a $\left(\mu \mathrm{g} \mathrm{I}^{-1}\right)$

TEP Density $\left(\times 10^{3} \mathrm{ml}^{-1}\right)$

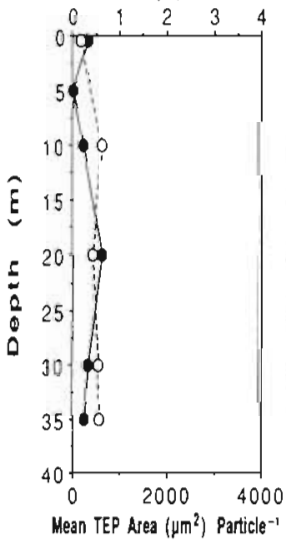

mesotrophic

eutrophic

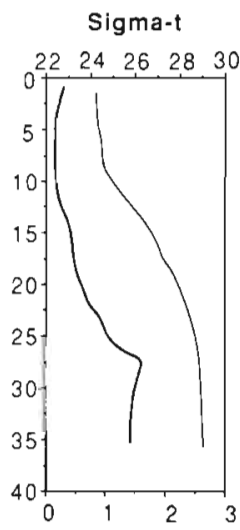

Chlorophyll $a\left(\mu \mathrm{g} \mathrm{I}^{-1}\right)$

TEP Density $\left(\times 10^{3} \mathrm{~m}^{-1}\right)$

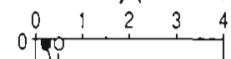

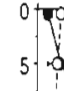

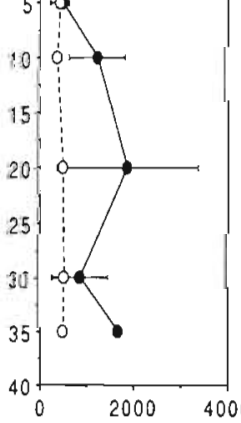

Meż TEP Area $\left(\mu m^{2}\right)$ Particle-1

\section{Sigma-t}

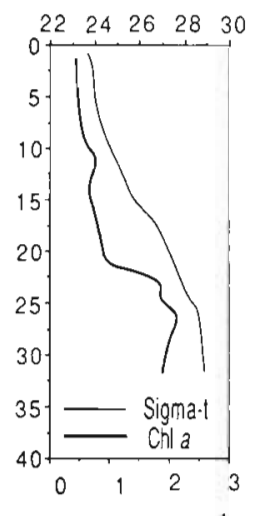

Chlorophyll a $\left(\mu \mathrm{g} \mathrm{I}^{-1}\right)$

TEP Density $\left(\times 10^{3} \mathrm{ml}^{-1}\right\}$

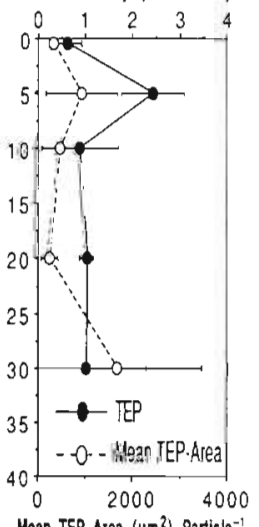

Fig. 2. August cruise. Profiles of sigma-t, chl $a$ and abundance of transparent exopolymeric particles (TEP) along the trophic gradient (oligotrophic: SJ107; mesotrophic: SJ105 and SJ103; eutrophic: SJ101 and SJ108)

to $900.9 \mathrm{nM}$ and from 108.4 to $471.8 \mathrm{nM}$, respectively, with no trend discernible towards higher concentrations in more eutrophic waters (Fig. 3). The same was true for dissolved polymeric (DPCHO; i.e. DTCHO $\mathrm{DMCHO}$ ) as well as for DMCHO. DPCHO concentrations were about 2 orders of magnitude higher than DMCHO concentrations; however, neither DCAA covaried with DFAA nor DPCHO with DMCHO (Fig. 3).

During the cruise in October 1993, the water column was characterized by freshwater input and resulting lower salinity in the surface layer of the water column (Fig. 4). This freshwater input caused by heavy precipitation coincided with a phytoplankton bloom as indicated by high chl a concentrations in the surface waters of the upper mixed layer (Fig. 4). Although the chl a concentrations declined over 2 orders of magnitude from the surface waters to $20 \mathrm{~m}$ depth, TEP abundance did not reflect this trend (Fig. 4). TEP abundance

was found to be even lower under these bloom conditions than in August when chl a concentrations were generally $<1 \mu \mathrm{g} \mathrm{chl} \mathrm{al^{-1 }}$ in the uppermost $15 \mathrm{~m}$ of the water column (cf. Figs. $2 \& 4$ ). Mean TEP area per particle was $210.8 \mu^{2}(\mathrm{SD}=266, \mathrm{n}=6)$ at the oligotrophic station, $344.1 \mu^{2}$ (SD $\left.=168.8, \mathrm{n}=11\right)$ at the mesotrophic station, and $363.7 \mu^{2}(\mathrm{SD}=330.4, \mathrm{n}=10)$ at the eutrophic stations. During these bloom conditions in October, bacterial abundance was about 1 order of magnitude higher than in August (Fig. 5). In October the percentage of TEP-attached bacteria was generally lower than in August; similar to August, however, the percentage of TEP-attached bacteria increased from the oligotrophic to the eutrophic stations (Fig. 5). The highest percentage of TEP-attached bacteria was only $0.41 \%$ of the total bacterial community in October. On average, $0.12 \times 10^{5}$ bacteria $\mathrm{ml}^{-1}$

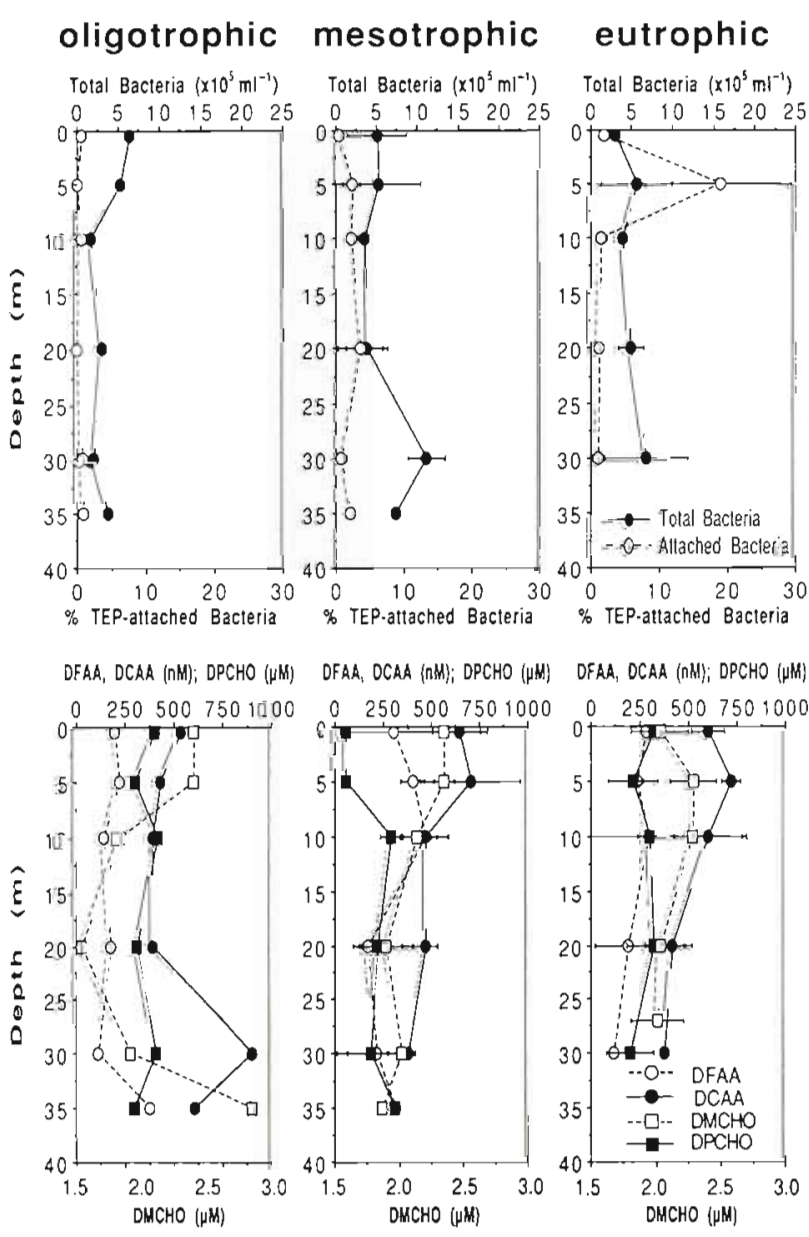

Fig. 3. August cruise. Upper panels: percentage of TEPattached bacteria (broken line) and total (free-living and attached) bacterial abundance (full line). Lower panels: concentration of dissolved free (DFAA) and combined (DCAA) amino acids and dissolved monomeric (DMCHO) and polymeric (DPCHO) carbohydrates in the water column of different trophic stages 
oligotrophic mesotrophic
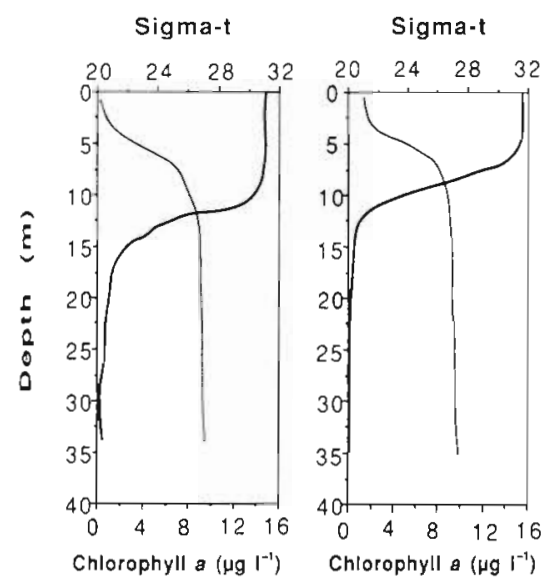

eutrophic
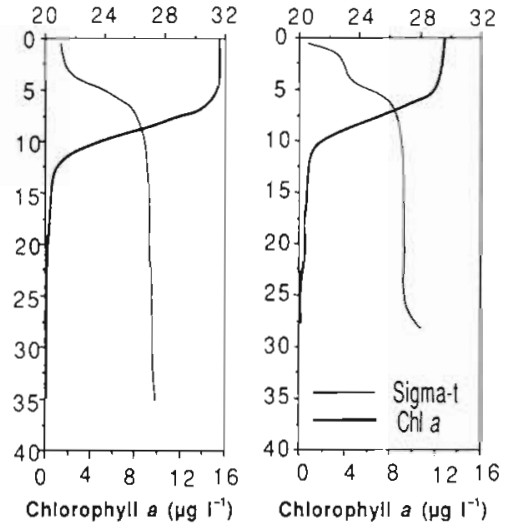

TEP Density $\left(\times 10^{3} \mathrm{ml}^{-1}\right)$

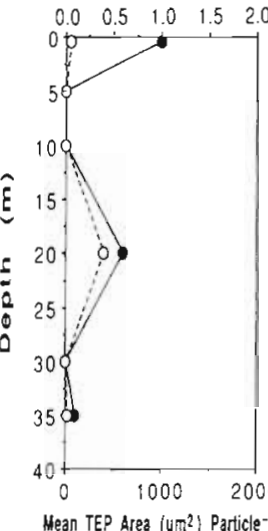

TEP Densily $\left(\times 10^{3} \mathrm{ml}^{-1}\right)$

$\begin{array}{lllll}0.0 & 0.5 & 1.0 & 1.5 & 2.0\end{array}$

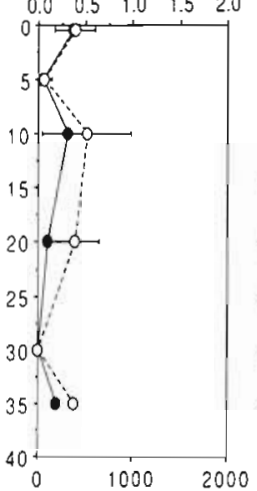

TEP Density $\left(\times 10^{3} \mathrm{~m}^{-1}\right)$
$\begin{array}{lllll}0.0 & 0.5 & 1.0 & 1.5 & 2.0\end{array}$

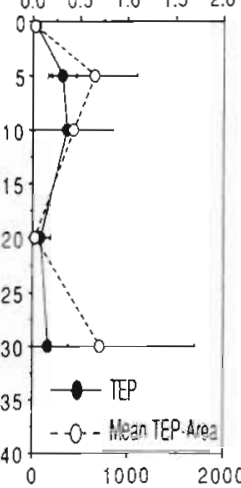

Hean TEP A Nea (um:2) Particle ${ }^{-1}$ Hean TEP hrea $\left(\mathrm{um}^{2}\right)$ Particle ${ }^{-1}$

Fig. 4. October cruise. Profiles of sigma-t, chl a and TEP abundance along a trophic gradient (oilgotrophic: SJ107; mesotrophic: SJ105 and SJ103; eutrophic: SJ101 and SJ108)

were attached to TEP in August while in October 0.02 $\times 10^{5}$ bacteria $\mathrm{ml}^{-1}$ were TEP-attached. While in August the concentration of DCAA was $\sim 2$ times higher than the DFAA concentration, they were more or less equal in October when DCAA and DFAA ranged from $250.4 \mathrm{nM}$ to $891.7 \mathrm{nM}$ and from $175.6 \mathrm{nM}$ to $996.4 \mathrm{nM}$, respectively (Fig. 5). DMCHO remained remarkably constant over both depths and stations while DPCHO increased from oligotrophic to eutrophic stations (Fig. 5).

\section{Laboratory experiments}

In a batch culture of Chaetoceros sp. to which a natural bacterial community was inoculated, the dynamics of TEP abundance were followed (Fig. 6). For the initial $30 \mathrm{~h}$ of this microcosm experiment, TEP abundance increased slightly from $-11 \times 10^{3} \mathrm{ml}^{-1}$ to $\sim 13 \times 10^{3} \mathrm{ml}^{-1}$, declined rapidly thereafter and remained low until the end of the experiment (Fig 6). Even when phytoplankton entered exponential growth (60 to $120 \mathrm{~h}$ after starting the experiment; Fig. 6) TEP concentrations remained at low levels. After $80 \mathrm{~h}$, the concentration of DCAA started to increase followed by bacteria after $120 \mathrm{~h}$. At $144 \mathrm{~h}$, phytoplankton entered stationary phase and concomitantly aggregate formation occurred making enumeration of TEP impossible. In exponentially growing phytoplankton, a thin layer stained with Alcian Blue surrounding the cell was always clearly visible. In the senescent stage, this halo stained with Alcian Blue increased in size, and sheets of mucus partly detached from the cell surface were observed. When senescent phytoplankton cells started to aggregate, Alcian Blue-stainable material formed a matrix in which phytoplankton and bacterial cells were embedded.

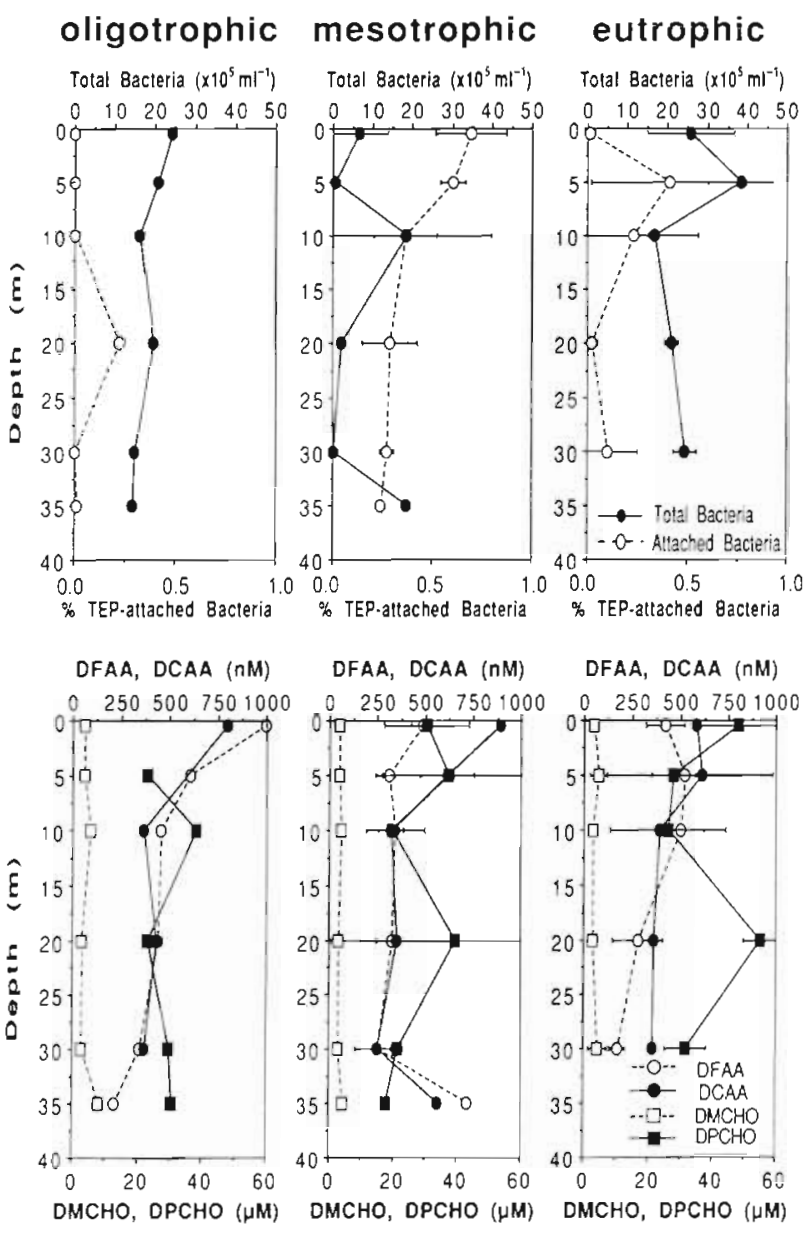

Fig. 5. October cruise. Upper panels: percentage of TEPattached bacteria (broken line) and total (free-living and attached) bacterial abundance (full line). Lower panels: concentration of dissolved free (DFAA) and combined (DCAA) amino acids and dissolved monomeric (DMCHO) and polymeric (DPCHO) carbohydrates in the water column of different trophic stages 


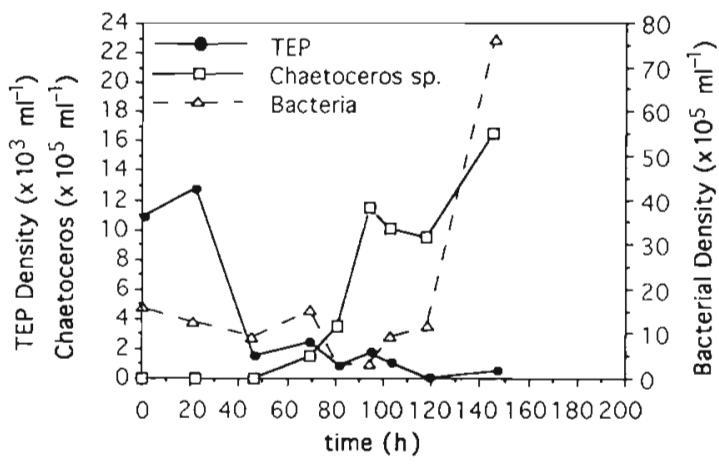

Fig. 6. Time course of the development of Chaetoceros $\mathrm{sp}$ density, free-living bacteria and the abundance of TEP in a rolling tank at $100 \mu \mathrm{E} \mathrm{m} \mathrm{m}^{-2} \mathrm{~s}^{-1}$. The experiment was ceased when Chaetoceros sp. entered late stationary phase releasing

large masses of TEP, which made counting impossible

In another set of microcosm experiments, the role of bacteria and turbulence on the formation and dynamics of TEP was investigated (Fig. 7). Water from a senescent Chaetoceros sp. culture was filtered through a Whatman GF/F filter and either placed on the rolling table or left undisturbed (Fig. 7). In both the turbulent and stagnant treatment 1 set of jars was fixed with formalin to prevent microbial activity (Fig. 7). The DOM added to the incubation jars consisted of $0.14 \mu \mathrm{M}$ DFAA, $1.8 \mu \mathrm{M}$ DCAA, $1.4 \mu \mathrm{M}$
DMCHO and $8.9 \mu \mathrm{M}$ DPCHO. TEP were readily detectable after $1 \mathrm{~h}$ and increased sharply in total area until $4 \mathrm{~h}$ after starting the experiment (Fig. 7, upper panels). Mean area of the TEP in the formalinfixed incubations reached only about half the area of the untreated incubations. The number of TEP as well as the total TEP area per $\mathrm{ml}$ (i.e. number multiplied by mean area) increased rapidly within the first hours regardless of the treatment (Fig. 7, upper panel). After this initial peak in TEP abundance and area, TEP declined; in the turbulent treatments, however, TEP area per $\mathrm{ml}$ remained more stable while under stagnant conditions TEP area declined rapidly; in none of the treatments were TEP detectable after $277 \mathrm{~h}$ (Fig. 7, upper panels). The mean size of TEP varied over the incubation period (Fig. 7, lower panels); under turbulent conditions the mean size of TEP increased over 4 to $24 \mathrm{~h}$; no significant difference (Wilcoxon, $\mathrm{p}=0.345$ and $\mathrm{p}=0.893$, respectively) was found between the size of the TEP between the formalin-fixed and the untreated control under stagnant conditions while significant differences were detectable between formalin-fixed and untreated vessels under turbulent conditions (Wilcoxon, $p=0.043$ ). The size of TEP under untreated, turbulent conditions was more stable over a period of $55 \mathrm{~h}$, while in the formalin-fixed vessel the mean size of TEP dropped to about half the size within $56 \mathrm{~h}$ (Fig. 7, lower panels).

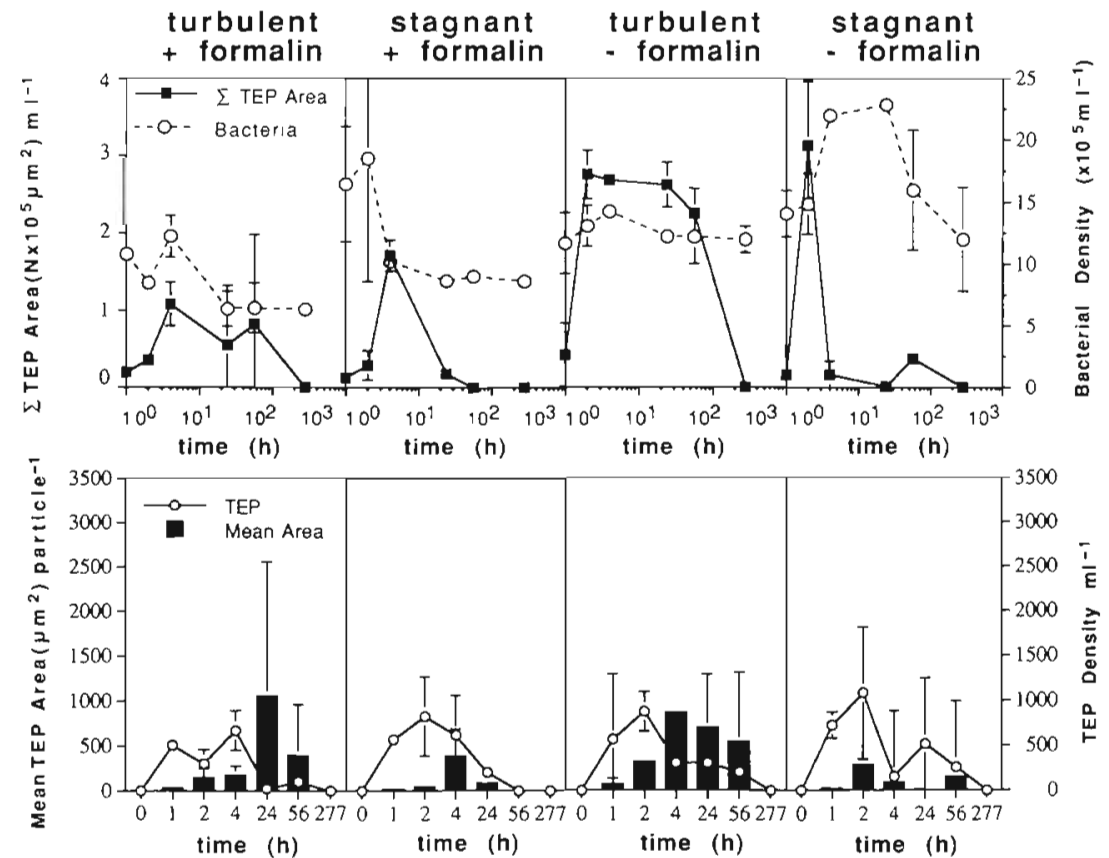

Fig. 7. TEP formation in $0.2 \mu \mathrm{m}$ filtered water derived from a senescent phytoplankton culture. Upper panels: development of total TEP area and bacterial abundance; lower panels: development of TEP abundance and mean TEP area per particle

\section{DISCUSSION}

Microscopic examination of TEP stained with Alcian Blue revealed that these TEP are abundant and represent a prominent component of organic carbon in the euphotic zone (Alldredge et al. 1993, Passow et al. 1994). In this study, enumeration and sizing of TEP were performed by directly filtering the particles stained with DAPI or Acridine Orange and Alcian Blue onto the polycarbonate filter and enumerating them under the microscope by switching between epifluorescence and transmission microscopy. By using this method, the filter-transfer-freeze technique can be avoided which might cause problems due to occasionally inefficient transfer of particles from the filter onto the glass slide (Herndl unpubl. data). 
During the cruises in August and October 1993 along a trophic gradient in the northern Adriatic Sea, we were able to detect TEP on all stations and in all depth layers which is in accordance to Alldredge et al. (1993), who report also a ubiquitous occurrence of TEP at coastal stations off California (USA). All the limited number of reports suggests that TEP are mainly derived from senescent phytoplankton cells (Kiørboe et al. 1990, Alldredge et al. 1993, Passow et al. 1994). In our study, we followed TEP abundance under 2 different ecological situations; while in October $1993 \mathrm{chl} \mathrm{a}$ concentrations were an order of magnitude higher than in August 1993 (Figs. 2 \& 4), TEP abundance was even lower during October (Fig. 4). This might indicate that juvenile, exponentially growing phytoplankton blooms, such as that detected during the October cruise, do not produce TEP in significant quantities. This conclusion is also supported by our laboratory experiments as shown in Fig. 6 and by Kiørboe et al. (1990). Laboratory experiments using diatoms demonstrated that the abundance of TEP increased towards the late stationary phase of the culture (Fig. 6) coinciding with elevated percentages of extracellular release (Myklestad \& Haug 1972, Obernosterer \& Herndl 1995). This extracellular release includes also colloidal material in varying quantities (Leppard \& Burnison 1990, Leppard 1992). Indeed, PCHO concentrations were up to 1 order of magnitude higher in August than in October, pointing to the potential importance of 'dissolved' polysaccharides for the formation of TEP in the water column, although no direct correlation between PCHO and TEP could be established

While there is evidence that sub-micrometer particles are not associated or colonized by microorganisms (Leppard 1992, Koike \& Tapas 1993, Wells \& Goldberg 1993), TEP were found to be readily colonized by bacteria (Fig. 8). TEP consist of a matrix of colloidal fibrils (Leppard \& Burnison 1990) onto which nitrogen-rich substances like amino acids can potentially adhere (Decho 1990), making these particles ideal sites for bacterial colonization. Both our in situ data and laboratory experiments demonstrate that smaller TEP are more densely colonized by bacteria than are larger TEP (Fig. 9). This pattern was also observed by Passow \& Alldredge (1994) and could be interpreted in different ways. It might indicate that smaller TEP are older than the larger ones allowing more time for bacteria to colonize them. It could also mean that due to bacterial ectoenzymatic activity, TEP are broken up into smaller units with a less hydrated state, leading ultimately to more dense TEP. Indeed, Smith et al. (1994) have shown that glucosidase additions to microcosms fragment marine snow, thereby creating numerous small aggregates. Another explanation of this characteristic distribution pattern of bacteria on

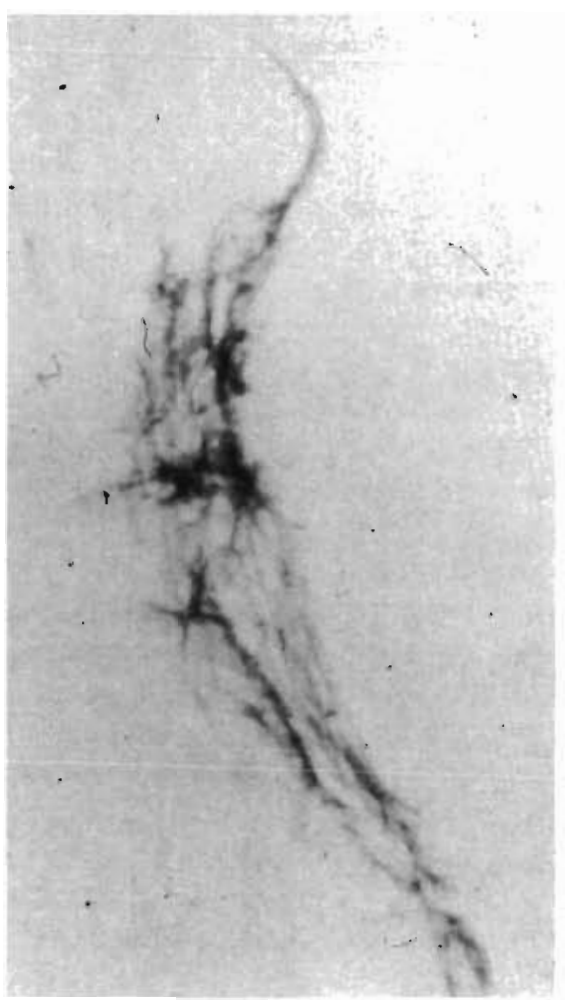

Fig. 8. Alcian Blue stained TEP from $5 \mathrm{~m}$ depth at Stn SJ 107 TEP is $128.8 \mu \mathrm{m}$ in length and $22.6 \mu \mathrm{m}$ in wadth

TEP would be increased adsorption of charged molecules including metals, resulting in a less hydrated state of the TEP as it ages. As shown in Fig. 7, TEP area per particle reached its maximum within $1 \mathrm{~d}$ in both the biotic and the abiotic treatment; this would indicate that the hydration state of the TEP is changed primarily by chemical processes rather than by biological activity. On the other hand, TEP abundance and mass rapidly declined in our incubation experiments (Fig. 7) in both the biotic and the abiotic treatment. Clearly, further experiments including measurements on bacterial activity are certainly necessary before a conclusive explanation on bacterial colonization patterns and on the degradation of TEP can be given.

Based on our batch culture experiments (Fig. 7) we may conclude that turbulence is more important for TEP formation than microbial activity. Obviously, turbulence facilitates colloidal fibrils and TEP to coagulate resulting in significantly larger mean areas per TEP than in the stagnant treatments (Fig. 7). Bacteria probably act as a stabilizing agent in TEP, possibly by releasing refractory DOM into the TEP matrix as observed by Heissenberger \& Herndl (1994) and Tranvik (1993), who found that bacteria release about $6 \%$ of the initially added labile substrate in the form of recalcitrant DOM. 

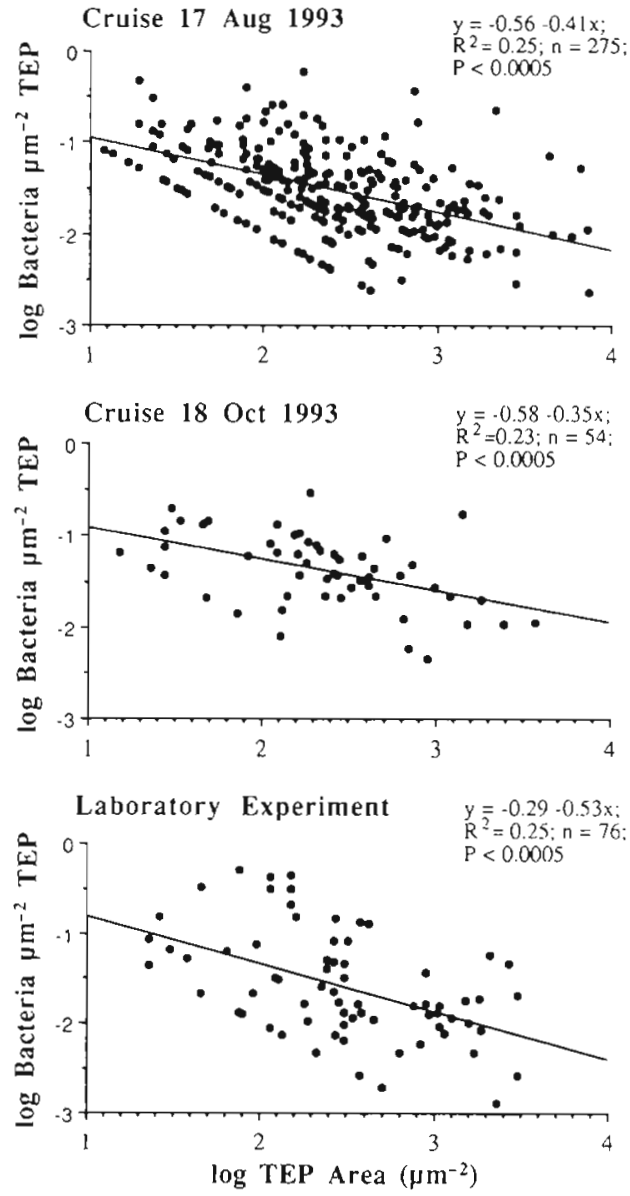

Fig. 9. Dependence of the number of TEP-attached bacteria on the size of individual TEP. Examples given for 2 cruises and 1 laboratory experiment

In summary, we have shown that TEP are a ubiquitous component of organic matter in the water column of the northern Adriatic Sea. TEP are relatively constant in abundance and obviously also in mass TEP neither varied considerably from oligo- to eutrophic conditions nor between different ecological situations (non-bloom vs phytoplankton bloom conditions) supporting the view that juvenile, actively growing phytoplankton cells do not contribute significantly to TEP formation - a notion also confirmed by laboratory experiments. Of crucial importance in the formation of TEP is turbulence of the water column superimposing the role of microorganisms. TEPattached bacteria are likely to stabilize the physical structure of TEP as indicated by a prolonged occurrence of larger TEP as compared to abiotic treatments. Despite the ubiquitous occurrence of TEP in the surface waters of the ocean no attempts have been made thus far to determine their importance in the carbon flux; future studies should focus on this aspect.
Acknowledgements. We thank the staff of the Center for Marine Research at Rovinj, Ruder Boskovic Institute, for hospitality and for providing shiptime, hydrocast data and laboratory space. We also thank the colleagues in our laboratory for help during this study. Financial support was provided by the Austrian Science Foundation (FWF) project no. 8608-BIO. The work is part of the fulfillment of the requirements towards a M.Sc. degree at the University of Vienna by S.S.

\section{LITERATURE CITED}

Aaronson S (1971) The synthesis of extracellular macromolecules and membranes by a population of the phytoflagellate Ochromonas danica. Limnol Oceanogr 16:1-9

Alldredge AL, Passow U, Logan BE (1993) The abundance and significance of a class of large, transparent organic particles in the ocean. Deep Sea Res I 40:1131-1140

Benner R, Pakulski JD, McCarthy M, Hedges JI, Hatcher PG (1992) Bulk chemical characteristics of dissolved organic matter in the ocean. Science 255:1561-1564

Burney CM (1986) Bacterial utilization of total in situ dissolved carbohydrate in offshore waters. Limnol Oceanogr 31:427-431

Burnison BK, Leppard GG (1983) Isolation of colloidal fibrils from lake water by physical separation techniques. Can J Fish Aquat Sci 40:373-381

Chrost RH, Faust MA (1983) Organic carbon release by phytoplankton: its composition and utilization by bacterioplankton. J Plankton Res 5:477-493

Decho AW (1990) Microbial exopolymers secretions in ocean environments: their role(s) in food webs and marine processes. Oceanogr mar Biol A Rev 28:73-153

Degobbis D, Smodlaka N, Skrivanic I, Precali R (1979) Increased eutrophication of the Northern Adriatic Sea. Mar Pollut Bull 10:298-301

Fogg GE (1977) Excretion of organic matter by phytoplankton. Limnol Oceanogr 22:576-577

Fogg GE (1990) Massive phytoplankton gel production. In Barth H, Fegan L (eds) Eutrophication-related phenomena in the Adriatic Sea and other Mediterranean coastal zones. Water pollution research report 16. Commission of the European Communities, Brussels, p $207-212$

Heissenberger A, Herndl GJ (1994) Formation of high molecular weight material be free-living marine bacteria. Mar Ecol Prog Ser 111:129-135

Herndl GJ (1992) Marine snow in the northern Adriatic Sea: possible causes and consequences for a shallow ecosystem. Mar microb Food Webs 6:149-172

Herndl GJ (1995) Microbial dynamics in marine snow. In: Wassermann P (ed) Proc Sediment Trap Studies in Nordic Countries. (in press)

Hoagland KD, Rosowski JR, Gretz MR, Roemer SC (1993) Diatom extracellular polymeric substances: function, fine structure, chemistry, and physiology. J Phycol 29:537-566

Hobbie JE, Daley RJ, Jasper S (1977) Use of Nuclepore filters for counting bacteria by epifluorescence microscopy. Appl environ Microbiol 33:1225-1228

Johnson KM, Sieburth JM (1977) Dissolved carbohydrates in seawater. I. A precise spectrophotometric analysis for monosaccharides. Mar Chem 5:1-13

Kaltenböck E. Herndl GJ (1992) Ecology of amorphous aggregations (marine snow) in the Northern Adriatic Sea: IV. Dissolved nutrients and the autotrophic community associated with marine snow. Mar Ecol Prog Ser 87:147-159

Kepkay PE (1994) Particle aggregation and the biological 
reactivity of colloids. Mar Ecol Prog Ser 109:293-304

Kepkay PE, Niven SE, Milligan TG (1993) Low molecular weight and colloidal DOC production during a phytoplankton bloom. Mar Ecol Prog Ser 100:233-244

Kiorboe T, Andersen KP, Dam HG (1990) Coagulation efficiency and aggregate formation in marine phytoplankton. Mar Biol 107:235-245

Koike I, Hara S, Terauchi K, Kogure K (1990) Role of submicrometre particles in the ocean. Nature 345:242-244

Koike I. Tapas L (1993) Total dissolved nitrogen in the North Pacific assessed by a high-temperature combustion method. Mar Chem 41:209-214

Lancelot C (1983) Factors affecting phytoplankton extracellular release in the Southern Bight of the North Sea. Mar Ecol Prog Ser 12:115-121

Leppard GG (1986) The fibrillar matrix component of lacustrine biofilms. Wat Res 20:697-702

Leppard GG (1992) Size, morphology and composition of particulates in aquatic ecosystems: solving speciation problems by correlative electron microscopy. Analyst 117 : 595-603

Leppard GG, Burnison BK (1990) Transmission electron microscopy of the natural organic matter of surface waters. Analyt Chim Acta 232:107-121

Leppard GG, Massalski A, Lean DRS (1977) Electron-opaque microscopic fibrils in lakes: their demonstration, their biological derivation and their potential significance in the redistribution of cations. Protoplasma 92:289-309

Lewin RA (1956) The mucilage tubes of Amphipleura rutilans. Limnol Oceanogr 1:111-113

McCave IN (1984) Size spectra and aggregation of suspended particles in the deep ocean. Deep Sea Res 31:329-352

Mopper K, Lindroth P (1982) Diel and depth variations in dissolved free amino acids and ammonium in the Baltic Sea determined by shipboard HPLC analysis. Limnol Oceanogr 27:336-347

Myklestad S, Haug A (1972) Production of carbohydrates by the marine diatom Chaetoceros affinis var. willei (Gran) Hustedt. I. Effect of the concentration of nutrients in the culture medium. J exp mar Biol Ecol 9:125-136

Myklestad S, Holm-Hansen O, Vârum KM, Volcani BE (1989) Rate of release of extracellular amino acids and carbo-

This article was submitted to the editor hydrates from the marine diatom Chaetocerus affinis. J Plankton Res 11:763-773

Obernosterer I, Herndl GJ (1995) Phytoplankton extracellular release and bacterial growth: dependence on inorganic N:P ratio. Mar Ecol Prog Ser 116:247-257

Painter RJ (1983) Algal polysaccharides. In: Aspinall GO (ed) The polysaccharides. Academic Press, New York, p $196-286$

Parsons T, Maita Y, Lalli C (1984) A manual of chemical and biological methods for seawater analysis. Pergamon Press, Oxford

Passow U, Alldredge AL (1994) Distribution, size and bacterial colonization of transparent exopolymer particles (TEP) in the ocean. Mar Ecol Prog Ser 113:185-198

Passow U, Alldredge AL, Logan BE (1994) The role of particulate carbohydrate exudates in the flocculation of diatom blooms. Deep Sea Res 41:335-357

Porter KG, Feig YS (1980) The use of DAPI for identifying and counting aquatic microflora. Limnol Oceanogr 25: 943-948

Shanks AL, Edmondson EW (1989) Laboratory-made artificial marine snow: a biological model of the real thing. Mar Biol $101: 463-470$

Smith DC, Steward GF, Long RA, Dam HG, Azam F (1994) Enzymatic inhibition of particle aggregation during phytoplankton blooms. Ocean Sciences Meeting 47

Smodlaka N, Revelante N (1984) The influence of the Po river on the primary production of the Northern Adriatic with comments on the importance of the nanoplankton. Rapp Comm int Mer Medit 29:97-98

Strycek T, Acreman J, Kerry A, Leppard GG, Nermut MV, Kushner DJ (1992) Extracellular fibril production by freshwater algae and cyanobacteria. Microb Ecol 23:53-74

Tranvik LJ (1993) Microbial transformation of labile dissolved organic matter into humic-like matter in seawater. FEMS Microbiol Ecol 12:177-183

Wells ML, Goldberg ED (1991) Occurrence of small colloids in sea water. Nature 353:342-344

Wells ML, Goldberg ED (1992) Marine submicron particles. Mar Chem 40:5-18

Wells ML, Goldberg ED (1993) Colloid aggregation in seawater. Mar Chem 41:353-358

Manuscript first received: December 14, 1994

Revised version accepted: February 23, 1995 